\title{
O golpe nas ilusões democráticas e a ascensão do conservadorismo reacionário*
}

\author{
The coup in democratic illusions and the rise \\ of reactionary conservatism
}

\author{
Marcelo Braz \\ Professor associado da ESS/UFRJ/Rio de Janeiro, Brasil; \\ pesquisador do Nepem (Núcleo de Estudos e Pesquisas Marxistas). \\ reis.braz@yahoo.com
}

\begin{abstract}
Resumo: Discutimos a crise brasileira e o processo político que levou à ascensão de um conservadorismo reacionário e ao impeachment de Dilma Rousseff. Procuramos mostrar de que forma as personagens centrais da conjuntura encarnam interesses reais de classes, especialmente aqueles vinculados ao capital financeiro e a seus agentes internos, bem como oferecer elementos para que o leitor entenda os limites da democracia no Brasil e os resultados da política de conciliação de classes em nosso país.
\end{abstract}

Palavras-chave: Crise. Democracia. Impeachment. Conservadorismo. Reacionarismo.

\begin{abstract}
In the article we discuss the Brazilian crisis and the political process that led to the rise of the reactionary conservatism and Dilma Roussef's impeachment. We have tried to show how the main characters of the situation embody real interests of the social classes, mainly those interests linked to the financial capital and its internal agents. We have also tried to offer elements for the reader to understand the limits of democracy in Brazil, and the results of the class coalition policy in our country.
\end{abstract}

Keywords: Crisis. Democracy. Impeachment. Conservatism. Reactionarism.

* O presente texto foi escrito para palestras e conferências que fiz para debater a conjuntura brasileira, realizadas entre maio e agosto de 2016. Uma primeira versão dele foi publicada na revista virtual Práxis e Hegemonia Popular, do IGS/Brasil (International Gramsci Society do Brasil), setembro de 2016. A versão que apresento agora retoma o texto com algumas modificações e acréscimos. Devo ao camarada Marcos Botelho, professor da ESS/UFRJ, algumas boas conversas sobre a conjuntura. As conclusões a que cheguei são de minha inteira responsabilidade. 
Falar aqui de forma de governo é triplamente estúpido, porque qualquer criança sabe que monarquia e república são formas de governo diferentes [...]. Somos pela república democrática como melhor forma de Estado para o proletariado sob o capitalismo, mas não temos o direito de esquecer que a escravatura assalariada é o destino do povo mesmo na república burguesa mais democrática.

(V. Lenine, A revolução proletária e o renegado Kautsky)

A exigência de abandonar as ilusões sobre sua condição é a exigência de abandonar uma condição que necessita de ilusões.

(K. Marx, Introdução, Crítica da filosofia do direito de Hegel)

\section{0 agosto de 2016 e o impeachment de Dilma Rousseff: tragédia e farsa na história do Brasil}

mês de agosto tem uma má fama. "Agosto, mês do desgosto", diz-se.
Na história política do Brasil temos eventos trágicos: em 24 de agos-
to de 1954 o presidente Getúlio Vargas se suicida, fato que abalou o país. Mais tarde, em 25 de agosto de 1961, o presidente Jânio Quadros surpreende ao pedir a renúncia do cargo poucos meses após tomar posse. Em 22 de agosto de 1976 o ex-presidente Juscelino Kubitscheck morre num estranho “acidente" de carro. Quarenta anos depois, no dia 31 de agosto de 2016, o Senado Federal votou o processo de impeachment que tirou a presidente Dilma Rousseff do cargo. Para quem acredita em crendices e superstições, o mês de agosto tem criado efemérides. Já para aqueles que procuram escapar das ilusões (como sugere Marx na epígrafe acima), o mês é apenas o oitavo do calendário gregoriano, que, por acaso, entrou para a história política no Brasil.

Ora, sabemos que a história é feita também de acasos. No entanto, o que associa o suicídio de Vargas à renúncia de Jânio, ao "acidente” de $\mathrm{JK}^{1}$ e ao

1. O "acidente" que matou JK até hoje levanta fortes suspeitas — ainda não comprovadas — de envolvimento da chamada Operação Condor. As suspeitas também pesam sobre a morte de Jango, no mesmo ano de 1976, em dezembro. O esquema de polícia política internacional, organizado em torno da Operação Condor, assassinou muitos opositores (legais e clandestinos) das ditaduras. Suas ações se iniciaram em 1975 , 
impeachment de Dilma não é nem o acaso nem a coincidência do "agourento" mês de agosto. O que os associa é a nossa história, que nos deixou um conjunto de problemas que permite identificar nos fatos recentes o legado do passado.

Todos os acontecimentos se deram em situações em que a democracia foi posta em questão, parcial ou inteiramente. Se, por um lado, foram motivados por circunstâncias particulares (se o suicídio e a renúncia foram atos cujo desenlace final dependeu de uma decisão individual, o "acidente" e o impeachment ocorreram para além das vontades individuais de quem os sofreu), há um fio que os amarra na história: ou serviram para acelerar um processo em que a democracia vinha sendo posta em questão; ou serviram para manter uma situação em que ela já havia sido abreviada. Em todos os casos tratava-se de criar (ou aprofundar) as condições mais adequadas para a hegemonia do grande capital entre nós. As formas podem ser as mais variadas, dependendo das possibilidades disponíveis às classes dominantes. Elas podem ser criadas por uma quartelada com apoio civil, por manobras judiciais, por arranjos parlamentares ou mesmo combinando-as. E há mais um elemento que os liga: em todos os casos os ataques à democracia contaram com o apoio ostensivo e militante dos grandes meios de comunicação.

Dilma, mesmo tendo feito um governo (como fizeram os governos petistas desde 2003) predominantemente voltado para os interesses do grande capital e de seus sócios brasileiros e, a partir de 2015, tendo adotado um programa de governo muito semelhante ao que foi apresentado (e derrotado) pelo candidato do PSDB em 2014, foi arrancada da presidência da República porque foi considerada incapaz de permanecer à frente dos interesses capitalistas que tanto serviu. Estes agora precisavam de um governo genuinamente burguês, capaz de não ceder o mínimo aos trabalhadores, de lhes retirar o pouco que conquistaram e

\footnotetext{
quando no Brasil a ditadura brasileira começava, com Geisel, a promover uma distensão política "lenta, segura e gradual". A distensão da ditadura foi, na verdade, vigiada e controlada. E no seu curso a ditadura promoveu ações violentas contra a oposição clandestina (PCB e PCdoB). A morte de JK é um entre outros tantos tristes episódios que marcaram a história da ditadura brasileira (1964-85). Em 2014 foram publicados vários bons livros que rememoraram a ditadura na ocasião em que se completavam cinquenta anos de seu início. Na impossibilidade de citar todos aqui, sugiro a leitura do excelente livro que José Paulo Netto fez para que não se esqueça, jamais, da ditadura, "pois se começa pelo esquecimento e se termina na indiferença" (Saramago): Pequena história da ditadura brasileira (1964-1985).
} 
de servir inteiramente, sem concessões, ao grande capital. O pacto de classes já não mais prestava.

\section{Um golpe nas ilusões democráticas. E uma derrota da conciliação de classes}

O governo Dilma, antes mesmo do golpe forjado por uma farsa parlamen$\operatorname{tar}_{\text {-judicial }}{ }^{2}$ que usurpou seu mandato, já agonizava desde 2015, inclusive por incompetências e erros. Foi sangrado até o último suspiro por seus algozes entrincheirados no Congresso Nacional e em amplos setores do Judiciário (com a aquiescência do douto STF) que contaram com as armas de uma Polícia Federal completamente partidarizada e, sobretudo, com as poderosas armas ideológicas da grande mídia burguesa. Criou-se uma situação, deliberada e irresponsavelmente, que afundou não apenas Dilma e seu governo, mas o próprio país foi levado a uma crise monumental que, para além de seus determinantes econômicos principais, foi piorada conscientemente pelas classes dominantes para que atingissem a qualquer custo seus objetivos políticos.

Entre os dias 25 e 31 de agosto ocorreu mais um pobre episódio de nossa pobre democracia. O palco foi o Senado. Não repetiu exatamente o show de horrores que foi o 17 de abril na Câmara dos Deputados, insuperável como espetáculo que apresentou aos brasileiros e ao mundo o nível desclassificado dos parlamentares. Não esqueceremos jamais um outro 17 de abril quando, em Eldorado dos Carajás, dezenove trabalhadores rurais sem terra foram assassinados em 1996 (há vinte anos, portanto). Mas a data ganha outra efeméride: o 17 de abril de 2016 entrará para a história como mais um triste capitulo de nossa pobre democracia.

Uma vez Lenin disse algo que a realidade tem lhe dado toda a razão: "O Parlamento é uma fábrica de cretinos". Vimos no Brasil, sem disfarces, até onde pode ir o cretinismo parlamentar. Na votação do impeachment vimos que a

2. A farsa evidenciou-se na peça jurídica que embasou o processo de impedimento da presidente, claramente forjada para tornar "crime de responsabilidade" alguns atos de governo (créditos suplementares envolvendo instituições do Estado) praticados na gestão. Tratou-se de uma operação claramente política voltada, exclusivamente, para suspender o mandato de Dilma Rousseff. 
maior fábrica dessa espécie de cretinice é a Câmara dos Deputados, presidida, até então, pelo maior dos cretinos e comandada na sua base pela chamada bancada BBB (Boi, Bala e Bíblia - latifundiários, empresários da indústria de armas e líderes evangélicos) que na verdade deveria ser BBBBB (Boi, Bala, Bíblia, Bola e Banca - os dois últimos representam a "cartolagem” do futebol e o sistema financeiro), a que se soma ainda a ação parlamentar dos representantes de poderosas empreiteiras.

Há um debate se aquilo se configurou num golpe. Uns acham que é um golpe branco; outros que é um golpe institucional — um misto do modelo hondurenho (que depôs Zelaya em 2009 com o aval da Suprema Corte) e paraguaio (que depôs Lugo em 2012 com o aval do Legislativo). No Brasil, a deposição da presidente adicionou mais ingredientes: contou com aval da Suprema Corte, do Legislativo, de parte ativa do Judiciário, da PF, com o apoio militante da nata do empresariado nativo, e, especialmente, dos oligopólios da mídia que agiram não como um "quarto poder", mas como se fossem o primeiro poder, pautando todos os outros.

Não achamos que isso se constituiu num golpe clássico, uma vez que se desenvolve sem rupturas institucionais significativas. Ao contrário, ocorre dentro do funcionamento regular das instituições democráticas burguesas, ou seja, com o aval da Justiça e do Legislativo. O impeachment vem se constituindo recentemente, em especial na América Latina, numa forma "democrática" de depor governos que, embora já tenham servido aos interesses do grande capital, já não servem ou os contrariam em alguma medida. As deposições de governos latino-americanos "inconvenientes" não têm resultado na instalação de ditaduras apoiadas nas forças militares e são feitas com rasgados discursos que apelam ao "republicanismo" e, claro, à democracia.

Um deputado desclassificado (Heráclito Fortes, ex-DEM, hoje PSB!) deu-nos uma contribuição insólita. Quando perguntado se houve golpe, ele saiu-se com uma pérola da cretinice parlamentar: disse que "se houve golpe, foi um golpe democrático". Sem querer, deu-nos talvez uma expressão paradoxal que na sua contradição revela o contraditório. O impeachment foi um "golpe democrático" operado no âmbito da democracia burguesa em funcionamento. Foi, assim, um golpe nas ilusões democráticas geradas pelos limites próprios da ordem burguesa (e de sua democracia), cuja condição cria suas próprias ilusões. 
Especialistas e organismos de diversas tendências (como o secretário-geral da OEA) afirmaram com alguma sinceridade que se as "instituições da democracia brasileira" estivessem funcionando, não teríamos o impeachment. Ao contrário: exatamente porque elas funcionaram é que foi possivel depor um governo eleito, porque não interessava mais que ele continuasse.

Todo esse preâmbulo serve para que não caiamos em duas tentações:

- Primeira: a de subestimar a democracia, mesmo que burguesa.

Sabemos que qualquer forma de república democrática é melhor que qualquer forma de ditadura. Seja qual for a estratégia política que adotamos, é na democracia que reunimos mais condições para avançar, lutar, resistir. Por isso, temos que denunciar qualquer tipo de recuo democrático como o que estamos vendo no momento. E não apenas por causa do impeachment, porque ele não é o único recuo democrático que estamos presenciando. Como veremos mais adiante, ele apenas é um atalho para mais recuos democráticos que estão se desenhando em todos os níveis da sociedade brasileira.

- Segunda: a de superestimar a democracia burguesa.

A democracia tem seus limites. Justamente porque é (e sempre será) democracia acompanhada por um adjetivo que lhe é inseparável (que, por ser-lhe inseparável, é-lhe quase um substantivo): a democracia é democracia burguesa! Que por ser restrita ao âmbito da sociedade capitalista não propicia uma participação real da massa do povo na direção/gestão do Estado, porque se esgota nos seus limites formais. É uma das formas políticas dessa sociedade. É capaz de promover alguns níveis de socialização da política, mas jamais poderá levar à socialização do poder político.

No Brasil, isso se torna mais complicado porque o modus operandi das classes dominantes sempre foi o de manter com a democracia uma relação exclusivamente instrumental. Ou seja, ela é útil quando favorece (ou não atrapalha) os interesses de classe dos dominantes. Assim foi em 1945, em 1954, em 1961, em 1964. Não necessariamente porque nesses momentos tínhamos governos que colidiam de maneira frontal com os interesses burgueses. Basta apenas existir um governo com algum "traço popular", algum traço reformista (mesmo um "reformismo fraco") — que já não mais sirva aos interesses dominantes - para que ele possa ser desestabilizado, por dentro e por fora, interna 
e externamente. E recordem que em praticamente todos esses momentos históricos lembrados, o mote da corrupção (ou o patriotismo, que é sempre "o último refúgio dos canalhas"... e dos covardes!) foi usado. Ora contra Getúlio, ora contra Jango, e até mesmo contra JK.

Temos no Brasil um histórico de soluções "pelo alto" que exclui os "de baixo" das instâncias decisivas que envolvem o poder político. E que reiteradamente golpeia aqueles que já não lhe servem ou que contrariem os interesses econômicos das classes dominantes. Assim, nem subestimemos nem superestimemos a democracia. E não tenhamos dúvidas de reagir, de ir à luta quando ela for atacada. É hora então de irmos à luta!

Mas antes de prosseguir, é necessário dizer que, apesar do "17 de abril" e do "31 de agosto", do rebaixamento ainda maior da nossa pobre democracia, tudo o que envolveu esse processo político que derrubou o governo Dilma pode nos servir como lição. Serviu para mostrar ao povo brasileiro, com transmissão ao vivo e em cores pela Rede Globo, em meio a sua nobre programação dominical, a podridão do sistema da democracia representativa do Brasil, para apresentar a quem não conhecia o nível de indigência moral e intelectual dos "representantes do povo" - aqueles que dominam a Câmara dos Deputados, a mal chamada "casa do povo". Mal chamada porque o povo, em sua maioria, não é aquela coisa vergonhosa, não é aquele horror, não é aquele circo com direito até a um palhaço profissional que envergonha sua categoria. O povo, em sua grande maioria (e é claro que estou falando da classe trabalhadora do nosso país), é constituído de gente honesta, honrada, trabalhadora, sempre disposta a arregaçar as mangas. Um povo trabalhador, generoso, alegre e festivo (cuja suposta cordialidade não tem nada de resignada, pois que é um povo lutador que derramou sangue por suas conquistas em tantas e tantas lutas inglórias, de norte a sul deste país). Um povo que "inventou a batucada pra deixar de padecer”, que se tornou musical como forma de reagir, por meio dessa expressão cultural, às portas sempre cerradas para o acesso à cultura letrada — às escolas e universidades de qualidade, privilégios do "andar de cima", desde que esse país se constituiu, "pelo alto", numa nação sem povo.

Nesse sentido, não apenas o "17 de abril" e o "31 de agosto", mas todo o processo político nesses seguidos meses de desestabilização do governo pode ter sido politicamente pedagógico. Aquela podridão não é o espelho do povo. 
Aquela autoimagem invertida quebrou o espelho. E um espelho quebrado pode até ser remendado, mas será sempre um espelho quebrado. Assim, nós podemos e devemos trabalhar junto às massas essa contradição do momento histórico que vivemos.

O momento pode ser pedagógico também porque foi revelador de vários traços importantes das classes dominantes, que se tornaram visíveis, didática e escandalosamente. O rei e seus súditos puseram-se nus! O Judiciário mostrou sua "imparcialidade", a mesma que usa com os "de baixo", contra os pobres que são julgados e encarcerados aos milhões por seus "atos contra as leis". A tal "imparcialidade" do Judiciário pode ser resumida assim: "Aos ricos: o favor da lei. Aos pobres: o rigor da lei!". No Brasil, o Judiciário é uma caixa-preta cujo funcionamento se dá com base em sistemas hierárquicos nos quais os ocupantes dos postos mais importantes não são eleitos pelo povo (no máximo são escolhidos entre seus pares). E as corporações que formam o sistema judiciário em nosso país consomem boa parte de nossa riqueza. Dados mostram que a Justiça custa ao Brasil 1,2\% do PIB (três vezes o programa Bolsa Família). Comparando-se com outros países, vê-se o tamanho da diferença: $0,34 \%$ na Venezuela, $0,32 \%$ na Alemanha, $0,28 \%$ em Portugal, $0,22 \%$ no Chile, $0,14 \%$ na Inglaterra e Estados Unidos, $0,13 \%$ na Argentina. Temos um custo alto para serviços de pouca qualidade e muito morosos.

O momento atual pode ser pedagógico também porque revela vários traços importantes das classes dominantes, tornando-os mais visíveis. Além do Judiciário que expôs sua "imparcialidade", os parlamentares (em especial os deputados) mostraram-se todos nus, sem disfarces, inclusive revelando pelo quê ou em nome de quem estavam votando, ainda que não tenham revelado seus financiadores legais e ilegais. $\mathrm{O}$ empresariado pagou, literalmente, o pato da avenida Paulista, repetindo a militância antidemocrática de amplos setores empresariais, como fizeram em 1964. Aliás, quem também se repetiu foi a OAB... E a grande mídia (em especial, mas não só, a Rede Globo) mostrou-se de fato o que é ao povo brasileiro: talvez o maior "partido" organizado das classes dominantes brasileiras. O padrão mais "sofisticado" (de sofisticada manipulação) do trabalho ideológico que faz em prol de seus objetivos foi abandonado em nome da sanha desestabilizadora. O conluio entre Legislativo, Judiciário, PF, mídia e organizações empresariais, como a Fiesp, foi explícito. Por tudo isso, esse 
momento pode ser politicamente pedagógico porque expôs as vísceras do poder do capital no Brasil e mostrou como suas maquinações intestinais funcionam.

Mas não devemos alimentar ilusões a esse respeito, pois a "normalidade" há de regressar e as máquinas ideológicas de representações que o poder dominante é capaz de criar já estão trabalhando para difundir o novo momento... a "solução" Temer.

O resultado produzido também pode nos mostrar que os últimos meses geraram uma vivência política que muitos não tinham ou haviam abandonado. Tomamos um banho de política (ainda que com a água suja e malcheirosa da "pequena política"!). Há muito que não se via tanta gente falando de política: nas ruas, nas escolas, no trabalho, nas reuniões familiares, no ônibus, no trem, no metrô, no táxi etc. É verdade que o ambiente imperante foi e é o da despolitização em todas as camadas da população brasileira. E sabemos também que as posições, mesmo entre muitos daqueles que eram contra o impeachment, valiam-se de argumentos bastante marcados por uma paixão cega que os impede de enxergar as razões da derrota do PT e de seu governo. De toda forma, o caráter abertamente antidemocrático, sem disfarces (ou com disfarces de legalidade) pode ter criado condições para desmistificar tanto os limites (e as ilusões) da democracia burguesa quanto, particularmente, pode ter servido para revelar o modus operandi das classes dominantes, que agiram em conluio à luz do dia e adotaram mais uma solução "pelo alto", mas dessa vez com a televisão, com o apoio do STF, de setores importantes do Judiciário, da PF e do Congresso Nacional.

E mais: talvez tenham sido dados alguns passos para superarmos uma das formas mais difundidas da ideologia dominante no Brasil assentada na visão de harmonia entre as classes, tão bem cultuada desde Vargas até Lula-Dilma. As condições atuais podem dificultar a reiteração de estratégias típicas da velha social-democracia, recauchutadas pela chamada Terceira Via e que ganhou sua versão tupiniquim nos governos do PT: a estratégia do "bom capitalismo", do "capitalismo de rosto humano".

Entretanto, de tudo ficou um gosto amargo de derrota, e não só para o PT, que é de fato o grande derrotado com sua estratégia de conciliação de classes. A derrota do PT respinga em toda a esquerda porque as máquinas ideológicas da classe dominante tratam de colocar todos no mesmo saco da "esquerda". 
Nesse sentido, é uma derrota que hipoteca o futuro das forças de esquerda no país pelo menos no curto prazo. O recuo democrático ao qual assistimos e que deverá se aprofundar tende a nos colocar na resistência aos ataques que vêm por aí, o que nos exigirá alguma unidade pelo menos tática. Isto não será nada fácil porque há segmentos da esquerda que comemoraram a derrota do PT como se fosse uma vitória da classe trabalhadora. Mais uma ilusão. Pior ainda: uma ilusão esquerdista que não enxerga que a conjuntura que se abriu com o impeachment expressa, antes de mais nada, uma vitória das forças à direita do PT, com fortes elementos de conservadorismo reacionário que trataremos ao final deste texto.

Sabemos que o essencial ainda está por vir. O derrube de Dilma e do PT significa mais que um atentado à democracia: significa, para as classes dominantes, que é hora de uma nova hegemonia que crie condições ideais para a reprodução dos interesses capitalistas num cenário novo que substitua a forma hegemônica que até então serviu. Ou seja, se a forma anterior já não é mais eficaz, trata-se de construir um novo bloco de poder para criar as condições ideais.

Há evidências de uma crise de hegemonia. Não exatamente aquele momento em que as classes dominantes já não podem governar como antes e tampouco as classes dominadas criaram as condições para se tornar classe dirigente. Pensamos numa crise de hegemonia que, como nos ensina Gramsci, em conjunturas recessivas comporta sempre o risco de impasses e de vácuos que podem levar a um desenlace dramático acompanhado pelo esgarçamento do tecido social e a explosão de particularismos. Nesses momentos, como o que estamos vivenciando, de transição entre formas hegemônicas, é comum que formas "bonapartistas" não clássicas sejam úteis. Não uma forma abertamente ditatorial, mas uma forma que conspira contra os avanços democráticos, e não só contra a democracia política, mas também contra os avanços sociais conquistados pela classe trabalhadora. Não exatamente uma forma abertamente fascista - devemos sempre lembrar que o fascismo é o regime político ideal para os monopólios - , mas uma forma que se valha de elementos fascistas, de uma cultura política fascista que ataque as conquistas democráticas.

O que está em jogo é a construção dessa nova hegemonia. E por isso estamos assistindo a uma luta intraburguesa ferrenha que está disputando a direção do novo bloco de poder. Mas não nos enganemos. Mesmo com todas as 
divergências no campo burguês há, entre suas diversas frações, uma unidade de ação entre elas. Tal unidade está na necessidade de acelerar as condições de aplicação de políticas que destravem os obstáculos (políticos, econômicos, sociais e ideológicos) para a implementação de uma agenda regressiva para a classe trabalhadora, em todos os níveis. Essa agenda está no documento "Uma ponte para o futuro", lançado pelo PMDB antes da deflagração do impeachment. Mas o central aqui é que o consenso burguês está na necessidade de acelerar contrarreformas profundas que atendam a quatro objetivos centrais (todos contemplados nas medidas que já tramitam no Congresso Nacional e que devem ser aceleradas):

- recolocar o Brasil (e a América Latina) na área de influência prioritária dos Estados Unidos no sentido de retomada, em condições ótimas, da sua dominância imperialista em nosso subcontinente;

- reduzir os custos do trabalho no país e aumentar a produtividade média do trabalho com base em novas formas de combinação de mais-valia relativa (incremento tecnológico para reduzir trabalho necessário e baratear a reprodução social da força de trabalho) e mais-valia absoluta (sobretudo via flexibilização das relações trabalhistas com vistas a atacar as formas de proteção social do trabalhador);

- implementar uma cruzada conservadora e reacionária contra os avanços sociais no campo das "minorias" como forma de promover um retrocesso cultural e ideológico no país;

- readequar as políticas sociais a um novo programa neoliberal mais radical de modo a criar condições para um ciclo profundo de políticas de austeridade fiscal que pesarão sobre os trabalhadores.

Por tudo isso, o momento é grave. E requer de nós prontidão, alguma unidade de ação para construir uma pauta de resistência ao que vem por aí. E o que vem por aí é o cerne de nosso problema e já podemos antecipar. Se olharmos atentamente para o documento "Uma ponte para o futuro" (que é mesmo uma ponte para a barbárie...) e também para o primeiro discurso oficial de Temer feito naquela fatídica sexta-feira 13 (de maio), em que assumiu a interinidade, veremos que há três linhas prioritárias que eles apontam: "ordem e progresso"; 
"privatizar tudo o que for possivel"; implementar uma tal "democracia da eficiência". Sabemos que, em síntese, essas três linhas de prioridade deverão colocar em ação medidas políticas e institucionais que combinem um quadro paradisíaco para o capital: maior repressão sobre os trabalhadores e melhores condições para a acumulação capitalista.

Isso dar-se-á, como foi dito, por meio de medidas, projetos de lei e decretos que poderão avançar. Eles são a forma concreta para aquilo que apontei: acelerar as condições para implementar uma agenda profundamente regressiva entre nós, não restrita à economia, como veremos abaixo. Alguns deles, como a MP n. 727, cria o Programa de Parcerias de Investimentos (PPI) para execução de empreendimentos públicos de infraestrutura e abre espaço para outras medidas de privatização. Foi aprovado pelo Senado no início de setembro e agora só depende da sanção de Temer. E essa MP dará as coordenadas para o "privatizar tudo o que for possível". Para este ano as prioridades do governo Temer são: aprovação da chamada PEC n. 241, dos gastos públicos, que prevê o congelamento de investimentos por vinte anos, inclusive para a Saúde e a Educação; ${ }^{3}$ e a contrarreforma da Previdência Social, que prevê desvinculação das pensões do salário mínimo, aumento da idade mínima e do tempo de contribuição.

Enquanto elas vêm sendo trabalhadas dedicadamente pela mídia burguesa, podem tramitar outros projetos que ameaçam os direitos. Reproduzo abaixo alguns projetos que vêm sendo denunciados pelos sindicatos e partidos ligados à luta dos trabalhadores:

- ataque às políticas sociais públicas e estatais que compõem a seguridade social em nosso país, como forma de avançar mais sobre o fundo público. As políticas sociais tendem a sofrer ataques no sentido de

3. O Ipea produziu recentemente boas análises que projetam para 2036 as consequências desastrosas que essa PEC n. 241 trará. Os pesquisadores do Ipea estimaram que a perda de receitas na área da Saúde pode chegar em R \$ 1 trilhão até 2036, dependendo das variações do PIB. Na Assistência Social, casos do programa Bolsa Família e do BPC, poderá ocorrer uma redução de aproximadamente R\$ 868 bilhões em duas décadas, uma perda de cerca de $50 \%$. Para maiores detalhes da pesquisa veja as fontes citadas (e os nomes dos autores) nas Referências bibliográficas no final deste artigo.

Lamentavelmente, a PEC n. 241 já foi aprovada em primeira instância pela Câmara dos Deputados (em 11/10/2016), até onde pude acompanhar quando concluí este artigo. A tramitação da PEC, que enfrentará pedidos de destaques da oposição, recursos judiciais que declaram sua inconstitucionalidade, ainda terá que passar em segunda instância na Câmara para depois seguir ao Senado. 
readequá-las ao novo período, por meio de formas de mercantilização (Previdência e Saúde, sobretudo) e de choques de gestão em busca de otimização e eficiência que tenderão a rebaixar direitos. No caso da Previdência, o fato de ela ter sido deslocada para a Fazenda já torna evidente o tratamento que terá. Será tratada, agora sem intermediações políticas inconvenientes, diretamente como questão financeira e atuarial. Não à toa foi escolhido um homem (que tem nome de ditador fascista português: Marcelo Caetano) do mercado (foi da BrasilPrev) para dirigir a nova secretaria criada para a área;

- risco de aumentar o escopo de políticas focalizadoras em detrimento das universais. E há mesmo uma tendência de tornar o Bolsa Família um programa mais focalizado. Se a ideia avançar, teremos uma inovação: uma focalização da focalização das políticas sociais. Mas o ataque principal não deverá se dar contra esse programa social, uma vez que ele custa pouco em relação a outros direitos assistenciais bem mais "onerosos", como os assegurados pela Loas (Lei Orgânica da Assistência Social), em particular as medidas já em curso que se voltam contra o BPC (Benefício de Prestação Continuada);

- alterações na legislação trabalhista com vistas a rebaixar os custos do trabalho, aumentar a produtividade média dos trabalhadores considerada baixa, flexibilizar ainda mais (lei das terceirizações) as relações de trabalho. Tal flexibilização visa criar formas que permitam aumentar a jornada de trabalho (como já confessou um imprudente ministro do Trabalho) ou até mesmo diminuí-la, mas com redução dos salários. Em todos os casos, buscarão avançar com uma contrarreforma trabalhista que tende a reforçar ainda mais a alta taxa de rotatividade da força de trabalho (uma das maiores do mundo). Antes disso, já vemos o avanço do discurso do "acordado sobre o legislado" que, na prática, vem alterando a legislação trabalhista;

- mais ataques às empresas públicas no sentido de privatizá-las ou de torná-las mais eficientes (estabelecimento de medidas mais duras de controle dos servidores, congelamento de salários, mais programas de PDV, limites ao direito de greve dos servidores, fim do abono permanência, retomada do Estatuto das Fundações). Quando não for possível 
a privatização (lembre que o lema é: "privatizar tudo o que for possível"), será adotado largamente o modelo das concessões via PPPs, que avançou tanto nos governos do PT e que encontra caminho regulamentar livre para se alastrar. Especificamente no caso da Petrobras, o novo marco regulatório (que literalmente entrega quase todo o "ouro negro" do Pré-Sal às grandes empresas das potências capitalistas) aprovado no Senado (obra de José Serra) deverá avançar rápido. Para o BNDES não foi à toa a escolha de Maria Sílvia Bastos Marques e de Elena Landau, comandantes das privatizações do governo FHC nos anos 1990;

- nova regulamentação/flexibilização da questão do trabalho escravo, de modo a excluir termos como "jornadas exaustivas" da analogia a formas de escravidão - uma exigência antiga dos latifundiários;

- redução da idade laboral (de dezesseis para catorze anos);

- redução da maioridade penal e aumento da internação de adolescentes infratores;

- Estatuto do Nasciturno (que aumenta a criminalização do aborto, tornando crime até mesmo os casos atualmente permitidos pela lei);

- Estatuto da Família (que retrocede enormemente os avanços dos direitos no campo da orientação sexual);

- aplicação da Lei Antiterror (triste herança de Dilma), que aumentará a repressão e colocará mais dificuldades ao nosso trabalho junto aos movimentos sociais.

\section{A reação conservadora e seus limites}

Essa agenda conservadora (que contém algumas propostas tipicamente reacionárias, como os estatutos da família e do nasciturno) não é apenas do PMDB e de seus apoiadores no Brasil (PSDB, DEM, PP, PR, PSB, PSD e outros menos cotados). É a atual agenda política e econômica do imperialismo para a América Latina, que, tendo nos Estados Unidos o seu centro de comando principal, encontra em vários de nossos países amplos setores burgueses associados e dependentes que lhe facultam apoio militante por todos os meios possíveis, legais 
e ilegais. Entre as grandes burguesias financeiras atuantes no subcontinente e entre outras frações burguesas a elas associadas e subordinadas se consolidou um consenso burguês em torno da necessidade de aceleração das condições ideais para a acumulação de capital. Tal necessidade de aceleração é muito determinada pela crise que se arrasta nas potências capitalistas e pela desaceleração da China, assim como pelas dificuldades que o imperialismo encontra (criadas por ele mesmo) em meio às guerras nos países da Ásia e do Oriente Médio. É esse cenário internacional da economia capitalista que coloca a América Latina na rota das prioridades imperialistas. O processo de retomada em condições ótimas dessa vasta zona de influência imperialista impõe uma partilha territorial e econômica que tem no Brasil um ponto estratégico fulcral. Nem Argentina (já retornada à órbita de influência), nem Venezuela (vítima de ataques desestabilizadores frequentes e que, até agora, sobrevive a eles a duras penas) e muito menos Bolívia e Equador têm o peso da economia brasileira.

Por fim, o impeachment foi feito, as ilusões foram perdidas e a nossa pobre democracia vê-se diante de mais um recuo profundo. Mas ela ainda oferece terreno para trabalharmos, mesmo que sob a "Lei Antiterror" que herdamos de Dilma, em suas contradições. O ilegítimo governo de Michel Temer tem apenas alguns meses de vida desde quando se instaurou, na prática, em 13 de maio de 2016. E terá até 2018 pouco mais de dois anos para saciar os anseios daqueles que o colocaram no poder. Ele tem diante de si três problemas, que se autodeterminam, dificilmente superáveis:

- nada ou ninguém lhe atribuirá algo que não tem: legitimidade. É, geneticamente, um governo ilegítimo, sem voto, impopular, fruto de uma fraude. Tal ilegitimidade está sendo questionada em fóruns internacionais e tem colocado alguma dificuldade para o reconhecimento do governo, como se viu na última assembleia da ONU realizada em setembro. A vitória dos defensores do impeachment não significa que conseguirão moldar um novo bloco de poder coeso. Eles se articularam num leque bastante diverso de forças à direita, desde os parlamentares, a grande mídia, os setores empresariais, o Judiciário e parte da população mais vinculada às camadas médias das maiores capitais. Uniram-se e se moveram pelo ódio ao PT e pela necessidade de uma nova hegemonia que já mostra dificuldades de se edificar porque estão 
agora em disputa pela liderança do bloco. É evidente que o comando é do capital financeiro, mas uma nova forma política precisa ser encontrada para substituir a que existia. Portanto, terão dificuldades de levar Temer até o fim porque ele representou uma unidade condicionada até a consumação do impeachment. Nesse sentido, obtiveram uma vitória limitada. E também uma vitória de Pirro, pois que foi construída a preços tão altos que já estão sendo cobrados (lembre o que disse Pirro a um combatente mais festivo que parecia não perceber os limites da vitória: "uma outra vitória como esta o arruinaria completamente"). Por isso, nem aquilo que todo governo tem à partida — um "voto de confiança", uma certa "lua de mel" — pode ser usufruído por esse governo;

- pelo que expusemos, vê-se que estamos diante de um governo marcado pela luta interna - que já está aberta (a unidade entre eles foi até o impeachment...) - , tanto pela liderança do novo bloco de poder que se desenha em meio à crise de hegemonia quanto pelo processo eleitoral que se avizinha (2018 já chegou em Brasília!). O PSDB já disse a que veio nos principais jornais do país por intermédio de seu príncipe. FHC afirmou, ${ }^{4}$ poucos dias depois do início do governo Temer, que seu partido sairá do governo ao primeiro sinal de que não dará certo. E ele disse em toda a entrevista que o governo não dará certo porque a crise é profunda e porque Temer não foi eleito e nem tem estatura para liderar o país... (mais claro que isso, impossível!). O homem do PSDB no STF (Gilmar Mendes) também já fez seu trabalho... Rapidamente mandou arquivar a investigação que sequer começou sobre Aécio Neves. E é bom lembrar que Gilmar agora está também na presidência do TSE;

- e, por fim, e mais importante: Temer tem pela frente uma brutal crise social (econômica e política) que, sob o ponto de vista capitalista neoliberal, vem corroendo todos os "bons" indicadores da economia brasileira. Resta-lhe um único caminho: a adoção de medidas profun-

4. O Globo, 13 maio 2016. 
damente impopulares e ainda mais recessivas (um amplo ajuste fiscal), isso diante de uma economia já no fundo do poço, de quebradeira generalizada de grandes empresas e de um desemprego galopante. $\mathrm{O}$ "mercado" the deu um cheque em branco: a escandalosa nova meta fiscal (R\$ 170 bilhões) que é mais que o dobro da pelo governo Dilma. Em troca, parece que há um pacto entreguista com o "mercado" estabelecido em torno do ataque aos direitos sociais e trabalhistas, do avanço sobre os recursos do fundo público e das privatizações. Certamente são medidas impopulares que piorarão a já péssima imagem de Temer junto à população trabalhadora (camadas médias inclusas).

De todo modo, esse quadro de dificuldades não sugere nenhuma posição otimista em relação às possibilidades políticas para as forças de esquerda no Brasil. Precisamos ter a clareza de que, como dissemos no início deste texto, a conjuntura que se abriu a partir do impeachment é de ascensão das forças mais conservadoras e até mesmo reacionárias que estão operando em todos os segmentos da sociedade brasileira — no Congresso Nacional, no Judiciário, nas forças policiais - e encontram respaldo em movimentos de direita financiados pela burguesia nativa e estrangeira que participaram das mobilizações para derrubar o governo. Tal conjuntura não criou um cenário abertamente fascista, como dissemos. Mas ela se alimenta de uma cultura fascista que se expressa das mais diversas formas de intolerância, inclusive o ódio ao PT, que não cessou com a queda de Dilma. Ao mesmo tempo, como parte dessa reação conservadora, vemos avançar um acordo, que é na verdade um arremedo de contrarreforma política, que prevê o estabelecimento de uma cláusula de desempenho eleitoral que na prática tenderá a inviabilizar os partidos políticos menores, fundamentalmente os de esquerda. Como deverá escapar dessa cláusula de barreira, o PT participa silenciosamente desse pacto entre os grandes partidos da direita.

A intolerância de nossas classes dominantes não é um fenômeno conjuntural. Historicamente elas sempre foram muito avessas a avanços sociais, mesmo aqueles que não comprometem os seus interesses econômicos. A nossa formação social nos legou uma classe dominante preconceituosa, mesquinha, egoísta, antidemocrática e violenta. Os traços herdados da escravidão constituíram 
marcas indeléveis em seu comportamento. A intolerância se volta com frequência contra os negros, ainda mais quando eles experimentam alguma mobilidade social, mesmo que pequena e intraclasse. Mas essa intolerância racista é também, fundamentalmente, classista. No Brasil, os ricos e seus sócios menores das camadas médias odeiam pobres. É por isso que Florestan Fernandes disse uma vez: "Contra a intolerância dos ricos, a intransigência dos pobres!".

Se o fascismo é uma forma política sempre possível desde quando os monopólios constituíram-se como dominantes na economia capitalista, no Brasil ele se amalgama com os elementos históricos de uma cultura de classe dominante que se alimenta do racismo. Junta-se a isso uma cultura política que, mesmo nos períodos republicanos, pouco avançou em relação à laicidade e que se alimenta também da intolerância religiosa. $\mathrm{O}$ avanço de elementos fascistas entre nós faz recrudescer ainda a misoginia que também foi usada contra a ex-presidente Dilma, ainda que não tenha sido a questão determinante para sua queda. Em todos os casos estamos diante de traços profundamente antidemocráticos que promovem no Brasil uma ascensão preocupante de forças conservadoras reacionárias. A chamada lei da mordaça ("Escola sem Partido") é talvez o melhor exemplo dessa ascensão.

Tal quadro coloca, pelo menos no curto prazo, imensas dificuldades para a sustentação de pautas políticas mais avançadas entre as forças de esquerda, sob pena de navegarmos num voluntarismo que será pouco eficiente na luta contra o reacionarismo que vivemos e os ataques que se voltam contra os interesses sociais do trabalho. Por isso talvez tenhamos que somar esforços no sentido de encontrar meios que possam construir, pelo menos no plano tático, um campo de unidade entre as forças democráticas e progressistas presentes não apenas nos organismos de classe dos trabalhadores, mas também entre setores mais amplos que se disponham a uma luta conjunta contra a reação conservadora.

Diante desse quadro de temeridades, devemos ter em mente todas as variáveis das lutas de classes que se aprofundam nos cenários de crise de hegemonia em conjunturas recessivas, como já lembramos a partir de Gramsci. Precisamos tê-los em mente para saber como enfrentar suas tendenciais consequências de fragmentação dos interesses que só favorecem aos particularismos de todo tipo, inclusive no seio das forças de esquerda. 
Contudo, mesmo diante de um cenário sombrio a classe trabalhadora brasileira - temperada por tantas lutas em conjunturas tão ou mais duras quanto esta em que vivemos - saberá, através de seus organismos de classe, independentes e autônomos, encontrar formas de resistir. E não apenas resistiremos. Superadas as ilusões dos últimos anos, podemos começar a criar as condições para um salto de consciência da classe trabalhadora brasileira.

Recebido em 4/10/2016 - Aprovado em 17/10/2016

\section{Referências}

CRISE POLÍTICA NO BRASIL: 2016. Disponível em: <http://marxismo21.org/wp-content/uploads/2016/06/>. Acesso em: 30 set. 2016.

FUNDAÇÃO ULISSES GUIMARÃES (PMDB). Uma ponte para o futuro. Brasília, 29 out. 2015.

LENINE, V. I. O Estado e a revolução: a doutrina do marxismo sobre o Estado e as tarefas do proletariado na revolução. In: Obras escolhidas em três tomos. Moscou/Lisboa: Edições Progresso/Edições Avante!, 1980. t. 2.

. A revolução proletária e o renegado Kautsky. In: . Obras escolhidas em três tomos. Moscou/Lisboa: Edições Progresso/Edições Avante!, 1981. t. 3.

MARX, K. Introdução. In: . Crítica da filosofia do direito de Hegel, 1843. São Paulo: Boitempo, 2010.

NETTO, J. P. Pequena história da ditadura brasileira (1964-1985). São Paulo: Cortez, 2014.

PAIVA, A. B. de et al. Nota técnica 27. NT 27 [bit.ly/2dchsMo]. Brasília: Ipea, 2016.

VIEIRA, F. S.; SÁ BENEVIDES, R. P. de. Nota técnica 28. NT 28 [bit.ly/2dInQ4j]. Brasília: Ipea, 2016. 